\title{
TERRORISM AND PARADIGM OF COMPARED CRIMINAL LAW
}

\author{
I.R. RUSU
}

\section{Ioana Raluca RUSU}

Doctoral School of Law

The Police Academy “Alexandru Ioan Cuza”, Bucharest, Romania

*Correspondence: Ioana Raluca Rusu, The Police Academy "Alexandru Ioan Cuza”, Aleea Privighetorilor 1-3, Bucharest 014031, Romania

E-mail: rusuioanaraluca@yahoo.co.uk

\begin{abstract}
The article is trying to briefly and generally present the philosophic and sociologic conceptions about paradigms regardless if these have been elaborated by specialists in the field of criminal law and how the influence of paradigm analyzed (paradigm of compared criminal law) reflects on terrorism by emphasizing the fact that a paradigm appears in the context of substituting the former ideas and acceptance without reserves of new.
\end{abstract}

KEYWORDS: paradigm, compared criminal law, terrorism, foreign fighter, lone wolf.

\section{INTRODUCTION}

A paradigm of compared criminal law in a field so difficult to approach, that of terrorism, appeared in the context of confrontation of ideologies in contradiction, confrontation of confessional perceptions and more recently of crisis of migrants came from Asia coinciding with the transformations determined by the concepts of "foreign fighter" and "lone wolf" which currently seem to merge and which have revealed extremely brutal a new side of terrorism and the need to explain new legislative interpretations and wishing that criminal branch is perceived as an antagonist contradiction, but positively, by the fact that old elements and out of use ideas which no longer answer to current requisites are substituted by new components and notions, resulting thus improvement and development of the process of prevention and fight against terrorist threat.

\section{BRIEF HISTORY}

"The determination and causality of phenomenon was and still is organized around five big paradigms, mainly when the object of study is the violence of movements and groups not directed by state". 1

Consequently, the paradigms of a system where chaos is present, are manifested and influence the system, including in case of terrorism such as the paradigm of crisis, instrumental paradigm, cultural paradigm, ideological paradigm, social paradigm, have been dealt with by philosophers, sociologists and other specialists in their works but a paradigm of compared criminal law from the perspective of prevention and combating terrorism has not been approached up to present.

In the vision of Thomas Samuel Kuhn, the paradigm is the exponent of a complex system combining technical, economic and socio-human concepts with a view to integrate the

\footnotetext{
${ }^{1}$ Gheorghe Arădăvoaice, Dumitru Iliescu, Laurențiu Dan Niță, Terorism, antiterorism, contraterorism - Istoric, actualitate, perspective, “Antet” Publishing House, Bucharest, 1997, p. 36.
} 
knowledge accumulated in scientific search ${ }^{2}$ for a transfer of ideas the target, in this case, being the development of a capacity of scientific understanding of compared law in case of occurrence of atypical situations. ${ }^{3}$

In fact, we may consider the search in the field of compared criminal law from the perspective of prevention and combating terrorist phenomenon as being an esoteric search due to the complexity of terrorist phenomenon manifested nowadays.

The appearance of a new paradigm does not represent a simple process by which the paradigm with a declining evolution is transformed by adding ideas and concepts but it maintains the base of former paradigm. The acceptance of the new ideas and concepts entails the disappearance of former paradigm and occurrence of new paradigms, although it solves only partially and for limited term the problems considered until substituted by a new paradigm generated by the phenomenon dynamism, does not represent but the axiom of progress ${ }^{4}$ in the scientific theory of the field studied and searched.

The manner how prevention and combatting terrorism is reflected in the legislation of word states and mainly in the manner how such states understand to approach unitarily the integration of activities of phenomenon counterattack in their own legislation based on resolutions, agreements, protocols and treaties elaborated by forums competent on world and regional level represents practically the base of occurrence of the paradigm of compared criminal law and development of legal system on global, regional and national level.

This paradigm has appeared as alternative to the need of improvement of order in order to reduce the negative restrictions which used to influence the society, pursuant to the division of parties which generates the chaos and which freely feeds the terrorist phenomenon.

The new manifestations of terrorism practically compel the authorities in charge with enforcement of law to order measures so as national criminal law of world states to interact more and more powerfully so that the ideas and concepts forming the base of knowledge of human conduct inclined to terrorist activity to converge to an effective collaboration based on unitary definitions related to terrorist phenomenon.

\section{CURENT LEGISLATIVE STATE ON LEVEL OF EUROPEAN UNION}

In the second half of $20^{\text {th }}$ century, the vision of European states influenced by the manner how terrorism is manifested on the national territory presents major differences related to the manner of combating the terrorist phenomenon. In the context of recrudescence of this phenomenon the need of approach with increased responsibility of elaboration of policies to combat the phenomenon has appeared being paid the equal attention to legislative, operative, logistic and financial fields by which one tries to restrict the terrorist activity and its consequences since the incipient phase.

The manner of manifestation of terrorism lately, trying to create chaos in society, has determined the amendment of the legislation of European Union and result an improved version to answer better the current requisites related to terrorist threats.

\footnotetext{
2 ... In other words, normal science is science by excellence. - Thomas S. Kuhn, Structura revoluțiilor științifice, translation from English by Radu J. Bogdan, "Humanitas" Publishing House, Bucharest, 2008, p. 21.

3 ... the history must compare the paradigms of community between them, as well as to the current search reports. Acting as such, the objective is to discover which isolable or implicit elements could be extracted by the members of such community, from ample paradigms, as enforced as rules in search - Thomas S. Kuhn, Structura revoluțiilor științifice, translation from English by Radu J. Bogdan, "Humanitas" Publishing House, Bucharest, 2008, p. 106.

${ }^{4}$... no paradigm ever solves all problems defined and since never two paradigms generate exactly the same problems unsolved, the controversies between paradigms are always addressing the question: which problems are the most important to be solved ? ... just due to turning to such external criteria the disputes between paradigms become revolutionary. - Thomas S. Kuhn, Structura revoluțiilor științifice, translation from English by Radu J. Bogdan, "Humanitas" Publishing House, Bucharest, 2008, p. 175.
} 


\section{TERRORISM AND PARADIGM OF COMPARED CRIMINAL LAW}

Relying on the frame Decision 2002/475/JAI of the Council for prevention of terrorism, dated $13^{\text {th }}$ June 2002, continuing with the Convention of Europe Council for prevention of terrorism, signed in Warsaw on $16^{\text {th }}$ May $2005^{5}$, the Decision 2005/671/JAI of Council related to information exchange and cooperation concerning the terrorism crimes, since $20^{\text {th }}$ September 2005, Directive 2013/40/EU of European Parliament and Council dated $12^{\text {th }}$ august 2013 on attacks against information systems and of substitution of frame Decision 2005/222/JAI of Council and reaching to the Directive (UE) 2017/541 of European Parliament and Council dated $15^{\text {th }}$ March 2017 on combatting terrorism and substituting the frame decision 2002/475/JAI of Council and for amendment of Decision 2005/671/JAI of Council, we determine that the anti-terrorist measures transposed in European legislation have been amended, and relying on it, there has been a permanent attempt to update the national legislations at least on the level of states members of European Union.

If the frame Decision 2002/475/JAI of the Council for prevention of terrorism has determined as terrorist actions 9 criminal acts to be committed with a certain scope stipulated by criminal law, the (EU) Directive 2017/541 of European Parliament and Council presents 10 criminal acts $^{6}$ which, if committed in the scope presented by the criminal norm, are classified as terrorist crimes.

A major difference between the two normative acts elaborated on the level of European Union is included in the definition of crimes related to terrorist activities. Therefore, if in the year 2002 only 3 such crimes have been defined, the decision from 2017 present minimum 10 facts incriminated as terrorist activity-related crimes.

Currently, although on the national level of the states of European Union one or several criminal acts in the field of prevention and combating terrorism could exist, such legislation relies on the legal norms from the years 2002 and 2005 and thus it is highly necessary to be transposed in the national legislation, preferably in a sole normative act and within a term as short as possible, the disposals of (EU) Directive 2017/541 of European Parliament and Council of $15^{\text {th }}$ March 2017 related to combating terrorism.

Considering that the individuals inclined to commit terrorism acts try to move, as much as possible, from one area to another within a short interval, they choose air routes and in order to supervise the transition of borders for the discovery of such individuals and restriction of their circulation in potentially terrorist areas, including European citizens enjoying free circulation, among the measures ruled, we may mention the incorporation of the Register with the names of passengers (PNR). ${ }^{7}$

Pursuant to analyzing the legislation of the states of European Union, we determine that antiterrorist and counter-terrorist measures rely on the disposals of the Directive of European Union of 2017, as follows:

"1. Administrative interdictions to leave or enter the national territory of some member states. The temporary interdictions may be extended to three years in a row. (i.e. France, Germany, Italy, Spain, Denmark, Netherlands).

2. Supervision in mass of telephones and use of internet. A variation of this category stipulates including the interdiction of coding the phone or internet conversations in progress

\footnotetext{
${ }^{5}$ On 15.06.2015, in Bruxelles, the Convention has been improved by the proposal of decision of Council related to signing, on behalf of European Union, the Convention of Europe Council related to prevention of terrorism.

${ }^{6}$ The new disposal rules the cyber attacks (cyber terrorism) - article 3 lett. (i) of (EU) Directive 2017/541 of European Parliament and Council dated 15th March 2017 on combatting terrorism.

${ }^{7}$ dr. Simona R. Soare, drd. Claudia M. Postelnicescu, European Institute of Romania, Strategic and Policy Studies SPOS 2015, study no. 5, Impactul noilor măsuri de combatere a fenomenului terorist, propuse la nivel european, asupra liberei circulații, Bucharest 2016, p. 41 - "According to the data updated in April 2015, supplied by FRONTEX, European agency in charge with supervision of cross border traffic in European Union (Schengen Space in particular), the highest number of foreign terrorist fighters who leave the European space and return to European Union are using the air route".
} 
at all big companies producing technology and mobile telephony. (i.e. Belgium, France, Great Britain, Italy, Romania).

3. Freezing the personal assets suspected/proved to be foreign terrorist fighters (ex. Great Britain, Germany, France, Belgium, Netherlands).

4. Withdrawal of citizenship and passports of individuals suspected/proved to be foreign terrorist fighters (i.e. Great Britain, Netherlands, and France).

5. Including in Criminal Codes the crimes related to the phenomenon of foreign fighters including the trip preparations in order to prepare/train in a terrorist camp or crimes related to online financing of terrorism. (ex. Germany, Denmark)". ${ }^{8}$

\section{TERRORIST CONCEPTS WHICH INFLUENCE THE OCCURRENCE OF NEW PARADIGMS}

The philosophy of terrorist synthesized as "foreign fighter" or "lone wolf" is both simple and complex. The philosophy is influenced by principles difficult to understand by normal people, as we perceive it, as we consider de decisions made primitive or phantasmagorical and senseless, but which for such terrorist represents the relation of self with divinity.

In the conceptions developed in time, the terrorist phenomenon has kept as main attribute the creation of terror, however, the manner of transposing it to practice has evolved from one epoch to another.

It is also the case of the so-called "foreign fighters" or "lone wolf", and their manner of action and motivation has been changed from one stage to another. If $4-5$ years ago the youth used to have as motivation the fight within Daesh ${ }^{9}$ in general by their perception of being isolated by the society in which they were living, will of revenge for different reasons or religious convictions, in time, this motivation has changed currently the motivation being the will of adventure. Also, the " foreign fighters" coming from states with a religion mainly catholic or orthodox from Europe have as main motivations the crisis of identity whereas some Muslim fighters came from Arabian states are motivated by the financial aspect to be able to maintain their families.

Currently, the states of European Union are facing a new scenario enforced by the supporters of Daesh namely the return home of jihadist to commit attacks in their states of origin, whereas "future is less the object of anticipations and more that of alternative scenarios". ${ }^{10}$

A similar situation is noticed as well in the case of the fighters, the so-called "lone wolf". If the attempt was "committed in the past by individuals with major psychical problems"11 and who were living in a restricted universe most of the times and were never leaving the locality of residence or the original country, currently, the terrorist attempts are committed by radicalized persons and trained abroad or who participated to armed conflicts as fighters of terrorist groups such as Daesh, al-Qaida ${ }^{12}$ etc.

We may say that the "lone wolf" of today is the "foreign fighter" from the past who returned home with a more radicalized conception and from different reasons with higher frustrations.

As previously shown in order to restrict the terrorist threats by the legislation adopted on the

\footnotetext{
${ }^{8}$ Dr. Simona R. Soare, drd. Claudia M. Postelnicescu, European Institute of Romania, Strategic and Policy Studies SPOS 2015, study no. 5, Impactul noilor măsuri de combatere a fenomenului terorist, propuse la nivel european, asupra liberei circulații, Bucharest 2016, p. 29.

${ }^{9}$ It is also known as Islamic State of Iraq and Syria (ISIS), Islamic State of Iraq and the Levant (ISIL), Islamic State (IS) or Daesh.

${ }^{10}$ Solomon Marcus, Paradigme universale. Pornind de la un zâmbet, "Paralela 45" Publishing House, Pitesti, 2006, p. 9

${ }^{11}$ Medeanu Tiberiu Constantin, Criminalistica în acţiune - Omorul, terorismul şi crima organizată, "Lumina Lex" Publishing House, Bucharest, tome II, 2006, p. 301.

${ }^{12}$ It is also known as al-Qaeda or al-Qaeeda
} 


\section{TERRORISM AND PARADIGM OF COMPARED CRIMINAL LAW}

level of European Union and not only, different measures have been ruled in the legislative, operative, logistic and financial field.

This paradigm, which we shall call paradigm of compared criminal law, the result of an assiduous work of harmonizing the anti-terrorist legislation in Europe must be appropriated and create concepts and work mechanisms by which the persons in charge with functions of decision from the governments of all world states to be open to dialogue and leaving behind the difficulties of the past, to encounter the language necessary to approach under all aspects the terrorist threat and to elaborate a legislative deed which may answer for a period as long as possible to an increasing number of common problems.

\section{CONCLUSIONS}

In order to cover the legislative gap and prevent the interpretations with negative influence on the activity of the authorities of law enforcement, the activity of prevention and combating terrorism may be construed as an abuse or more seriously as breach of human rights, most improvements were made in the field of crimes related to terrorism activity. Therefore, activities like recruitment, offering or receiving training in terrorist scopes, public instigation to commit a terrorism action and last but not least financing terrorism which in the past it used to be stipulated by documents complementary to that ruling the prevention and combating terrorism are ruled. Today, one tries to reach a harmony between the crisis generated by terrorist activities and the answer of authorities to this crisis, being observed the fundamental human rights and the European values obtaining with such effort.

Practically, the base of this article is not to analyze the implications of terrorism or its effects, it is represented by the process of encountering new paradigms on which may rely the approach in a new light of the elements, ideas or conceptions that must be changed for a unitary approach related to prevention and combating the terrorist phenomenon on level of the states of European Union.

\section{BIBLIOGRAPHY:}

\section{Legislation}

1. Directive (EU) 2017/541 of the European Parliament and of the Council of 15 March 2017 on combating terrorism and replacing Council Framework Decision 2002/475/JHA and amending Council Decision 2005/671/JHA;

2. Proposal for a Council Decision on the signing, on behalf of the European Union, of the Council of Europe Convention on the Prevention of Terrorism (CETS No. 196) of 15 June 2015

3. Directive 2013/40/EU of the European Parliament and of the Council of 12 August 2013 on attacks against information systems and replacing Council Framework Decision 2005/222/JHA;

4. Council Decision 2005/671/JHA of 20 September 2005 on the exchange of information and cooperation concerning terrorist offences;

5. Council of Europe Convention on the Prevention of Terrorism, signing to Warsaw, 16.V.2005;

6. Council Framework Decision of 13 June 2002 on combating terrorism, (2002/475/JHA).

\section{Specialized books}

7. Thomas S. Kuhn, Structurarevoluțiilorștiințifice, translation from english by Radu J. Bogdan, „Humanitas” Publishing House, Bucharest, 2008; 
8. Solomon Marcus, Paradigmeuniversale. Pornind de la un zâmbet, „Paralela 45” Publishing House, Pitesti, 2006;

9. MedeanuTiberiuConstantin, Criminalisticaînacţiune - Omorul, terorismulşicrimaorganizată, tome II, „Lumina Lex” Publishing House, Bucharest 2006;

10. Gheorghe Arădăvoaice, Dumitru Iliescu, Laurențiu Dan Niță, Terorism, antiterorism, contraterorism - Istoric, actualitate, perspective, „Antet” Publishing House, Bucharest, 1997.

\section{Other specialized writings}

11. Dr. Simona R. Soare, drd. Claudia M. Postelnicescu, European Institute of Romania, Strategic and Policy Studies SPOS 2015, study no. 5, Impactul noilor măsuri de combatere a fenomenului terorist, propuse la nivel european, asupra liberei circulații, Bucharest 2016.

Other sources - internet websites (accessed/visited between June and July 2017);

12. eur-lex.europa.eu;

13. www.ier.ro/sites;

14. https://lege5.ro/.../decizia-nr-671-2005-privind-schimbul-de-infor...;

15. https://www.juridice.ro/.../directiva-ue-2017541-parlamentului-eur...;

16. www.monitoruljuridic.ro/.../conventia-din-16-mai-2005-consiliului. 